\title{
Concise Communications: "Death of a Patient Aged 2.5 Years after Infection Cause Parainfluenza Virus Type 1"
}

Tecu C ${ }^{\star}$, Mihai ME, Alexandrescu VI and Lupulescu E

National Institute for Research and Development Microbiology and Immunology Cantacuzino, Respiratory Viral Infections Department, Bucharest, Romania

${ }^{*}$ Corresponding author: Tecu Cristina, National Institute for Research and Development, Microbiology and Immunology Cantacuzino, Respiratory Viral Infections Department, Bucharest, Romania, Tel: 0040749032041; E-mail: tecucristina@yahoo.com

Rec Date: Jun 08, 2014, Acc date: Sep 27, 2014, Pub date: Sep 29, 2014

Copyright: $\odot 2014$ Tecu C, et al. This is an open-access article distributed under the terms of the Creative Commons Attribution License, which permits unrestricted use, distribution, and reproduction in any medium, provided the original author and source are credited.

\begin{abstract}
Introduction: In this study we describe the identification of parainfluenzae virus (PIV) type 1 as the etiological agent of bronchopneumonia and cardio-respiratory failure which caused the death of a child aged of 2.5 years. The objective of the study was to show the possibility that infection with PIV 1 can causes death.

Case presentation: The patient had the diagnosis of SARI (Severe Acute Respiratory Infection) at the admission in the hospital, but few hours after the hospitalization, she died. Laboratory tests were within normal limits (total WBC and differential, serum immunoglobulins, liver transaminases, urinalysis, blood sedimentation rate) and the patient showed no associated diseases. We before tested the sample (fragment of the right lung) for the presence of influenza virus type $A$ and $B$ (including pandemic H1N1), because the patient became ill in the pandemic season 2009-2010. After that the detection of influenza viruses was negative, we tested the sample for the presence of the others respiratory viruses. In the same time, we tested if the specimen had the respiratory bacteria associated with. The Real-time PCR method for detection of $\mathrm{A} / \mathrm{H} 1 \mathrm{~N} 1$ pandemic virus and the Reverse Transcription-Polymerase Chain Reaction (RT-PCR) for detection of other non-influenza viruses (respiratory syncytial virus, human metapneumo virus, PIV 1, 2 and 3, Coronaviruses 229E and OC43) were used as diagnostic methods. In the same time, the Kit RV/PB18 ASE Detection (Seegene) was used in order to test a potential bacterial etiology of the infection (Streptococcus pneumoniae, Haemophilus influenzae, Legionella pneumophila, Mycoplasma pneumoniae, Chlamydophila pneumoniae).
\end{abstract}

Conclusion: Finding of this study is that although the patient has no experienced chronic diseases associated with, she died from a bronchopneumonia caused by PIV type1.

Keywords: Parainfluenza virus type 1(PIV 1); Real-time PCR; Reverse Transcription Polymerase Chain Reaction (RT-PCR); Bronchopneumonia

\section{Introduction}

PIV 1 (family Paramyxoviridae) is enveloped virus with a single, negative strand RNA genome. Parainfluenza viruses represent the most significant upper respiratory pathogens in infants, young children and adults. Similar to Respiratory Syncytial Virus (RSV), PIV can cause repeated infections throughout life. The 4 different types, 1 to 4, exist. Each of the four PIV has different clinical and epidemiological features. PIV 1 and 2 are major causes of laryngotracheobronchitis (croup). The severity of illness is greatest in children aged 2-4 years. Both PIV type 1 and 2 can cause other upper and lower respiratory tract illnesses. PIV type 2 is less frequently detected. PIV type 3 infections can lead to croup but, most notably, type 3 is second only to RSV as a cause of infant bronchilitis and pneumonia. Illness from type 3 infections is most severe in infants less than 1 year old.

\section{Case Report}

The objective of the study was to show the possibility that infection with PIV 1 can causes death to a child aged 2.5 years, due bronhopneumonnia and cardio-respiratory failure. The patient had the diagnosis of SARI (Severe Acute Respiratory Infection) at the admission in the hospital, but few hours after the hospitalization, she died. Laboratory tests were within normal limits (total WBC and differential, serum immunoglobulins, liver transaminases, urinalysis, blood sedimentation rate) and the patient showed no associated diseases. We before tested the sample (fragment of the right lung) for the presence of influenza virus type A and B (including pandemic H1N1), because the patient became ill in the pandemic season 2009-2010. After that the detection of influenza viruses was negative, we tested the sample for the presence of the others respiratory viruses.In the same time, we tested if the specimen had the respiratory bacteria associated with. The result of these tests was the presence of major band appeared on agarose gel electrophoresis after carrying out RT-PCR as a positive control used in PIV type1. The amplicon was then analyzed by sequencing, showing that the etiological agent belonging to a group of viruses PIV type 1 .

\section{Investigations}

The sample from our patient aged 2.5 years and admitted in Botosani Pediatric Hospital (she died after few hours of hospitalization) was a fragment of right lung (sample no. 8705). The sample was brought to our laboratory on the same day and processed. 
Citation: Tecu C, Mihai ME, Alexandrescu VI, Lupulescu E (2014) Concise Communications: "Death of a Patient Aged 2.5 Years after Infection

Page 2 of 3

\section{Real time}

RT PCR was the method used to investigate whether the patient had influenza virus type A and type B (WHO Manual on Animal Influenza Diagnosis and Surveillance, WHO/CDS/CSR/NCS/2002.5, Rev.1, CDC Realtime RT-PCR (rRTPCR) protocol for Detection and Characterization of Swine Influenza (version 2009); CDC REF. \#I-007-05 (reaction protocol was done according to WHO instructions).

\section{RT}

PCR was the method used to investigate whether the patient had infection caused by other non-influenza viruses (RSV, human Metapneumovirus-hMPV, PIV 1,2,3, Corona Viruses 229E and OC43$\mathrm{CoV})$. Qiagen kit was used for extractions and one-step Qiagen kit for RT-PCR, according to manufacturer's instructions. The primers used for these viruses are shown in the Table 1. PCR products from RTPCR for all these non-influenza viruses were subjected to electrophoresis through a $1.5 \%$ agarose gel. The primers and amplicons size are shown in Tabel 1. The diagnosis of the 5 pneumonial bacteria, Seeplex RV/PB 18 ASE Detection was used according to manufacturer's instructions. The principle of this kit is a multiplex assay that permits the simultaneous amplification of target DNA of 5 bacteria, and Internal Control (IC).

\begin{tabular}{|c|c|c|c|c|}
\hline \multirow[t]{2}{*}{ No. } & \multirow[t]{2}{*}{ Viruses } & \multirow[t]{2}{*}{ Primers } & \multirow{2}{*}{$\begin{array}{l}\text { Amplicon } \\
\text { size (bp) }\end{array}$} & \multirow[t]{2}{*}{ Reference } \\
\hline & & & & \\
\hline \multirow[t]{2}{*}{1} & \multirow[t]{2}{*}{ RSV } & $\begin{array}{l}\text { Fw: 5' GGA ACA AGT TGT } \\
\text { TGA GGT TTA TGA ATA } \\
\text { TGC 3' }\end{array}$ & \multirow[t]{2}{*}{278} & \multirow[t]{2}{*}{1} \\
\hline & & $\begin{array}{l}\text { Rv: 5' CTT CTG CTG TCA } \\
\text { AGT CTA GTA CAC TGT } \\
\text { AGT 3' }\end{array}$ & & \\
\hline \multirow[t]{2}{*}{2} & \multirow[t]{2}{*}{ hMPV } & $\begin{array}{l}\text { Fw: 5'GCT TCA GTC ATT } \\
\text { CAA CAG 3' }\end{array}$ & \multirow[t]{2}{*}{150} & \multirow[t]{2}{*}{2} \\
\hline & & $\begin{array}{l}\text { Rv: 5' CCT GCA GAT GTT } \\
\text { GGC ATG T 3' }\end{array}$ & & \\
\hline \multirow[t]{2}{*}{3} & \multirow[t]{2}{*}{ PIV1 } & $\begin{array}{l}\text { Fw: 5'CCG GTA ATT TCT } \\
\text { CAT ACC TAT G 3' }\end{array}$ & \multirow[t]{2}{*}{317} & \multirow[t]{2}{*}{3} \\
\hline & & $\begin{array}{l}\text { Rv: 5' CCT TGG AGC GGA } \\
\text { GTT GTT AAG 3' }\end{array}$ & & \\
\hline \multirow[t]{2}{*}{4} & \multirow[t]{2}{*}{ PIV2 } & $\begin{array}{l}\text { Fw: 5' AAC AAT CTG CTG } \\
\text { CAG CAT TT 3' }\end{array}$ & 517 & \\
\hline & & $\begin{array}{l}\text { Rv: 5' ATG TCA GAC AAT } \\
\text { GGG CAA AT 3' }\end{array}$ & & 3 \\
\hline \multirow[t]{2}{*}{5} & \multirow[t]{2}{*}{ PIV3 } & $\begin{array}{l}\text { Fw: 5' CTC GAG GTT GTC } \\
\text { AGG ATA TAG 3' }\end{array}$ & \multirow[t]{2}{*}{189} & \multirow[t]{2}{*}{3} \\
\hline & & $\begin{array}{l}\text { Rv: 5' CTT TGG GAG TTG } \\
\text { AAC ACA GTT 3' }\end{array}$ & & \\
\hline \multirow[t]{2}{*}{6} & \multirow[t]{2}{*}{ CoV 229E } & $\begin{array}{l}\text { Fw: 5' TGG CCC CAT TAA } \\
\text { AAA TGT GT 3' }\end{array}$ & \multirow[t]{2}{*}{573} & \multirow[t]{2}{*}{3} \\
\hline & & $\begin{array}{l}\text { Rv: 5' CCT GAA CAC CTG } \\
\text { AAG CCA AT 3' }\end{array}$ & & \\
\hline 7 & $\begin{array}{l}\text { CoV } \\
\text { OC43 }\end{array}$ & $\begin{array}{l}\text { Fw: 5' GGC TTA TGT GGC } \\
\text { CCC TTA CT 3' }\end{array}$ & 335 & 3 \\
\hline
\end{tabular}

\begin{tabular}{|l|l|l|l|}
\hline & $\begin{array}{l}\text { Rv: 5' GGC AAA TCT GCC } \\
\text { CAA GAA TA 3'. }\end{array}$ & \\
\hline
\end{tabular}

Table 1: The primers and amplicons size are shown.

The size of the amplicons (bp) were: IC-850; Legionella pneumophila-753; Streptococcus pneumoniae-67; Chlamydophila pneumoniae-593; Haemophilus influenzae-534; Mycoplasma pneumoniae-469.

\section{Sequencing}

Sequencing (using primers RT-PCR) was done with the device 3100-Avant Genetic Analyzer, and sequences were edited with BioEdit, and the pattern was made by comparing the sequences deposited in data banks, with the help of BLAST (data not shown).

\section{Results and Discussions}

The result of Real-time PCR for the detection of influenza virus was negative. The analysis and interpretation of the results obtained from RT-PCR for other non-influenza viruses is presented in Figure 1. The analysis and interpretation of the results obtained from PCR for the 5 pneumonial bacteria is presented in Figure 2. The result of these tests was the presence of major band appeared on agarose gel electrophoresis after carrying out RT-PCR as a positive control used in PIV typel. The amplicon was then analyzed by sequencing, showing that the etiological agent belonging to a group of viruses PIV type 1.

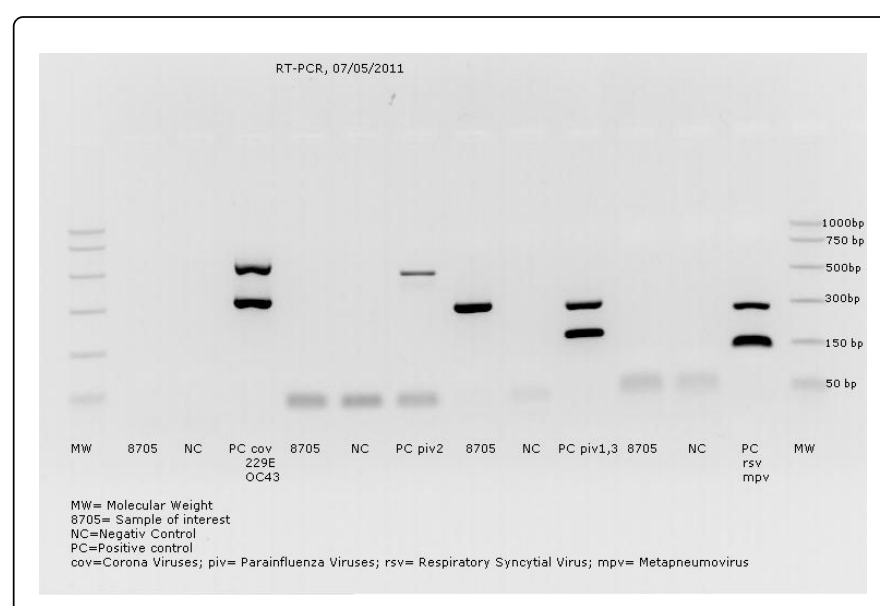

Figure 1: RT-PCR - Sample of interest 8705 appear like a major band on agarose gel electrophoresis as a positive control of PIV type $1(317 \mathrm{pb})$.

Biennial fall epidemics are the hallmark of PIV 1 and occur in both hemispheres [1-6]. Reports from the United States have suggested that a minimum of $50 \%$ of croup cases are caused by the virus $[5,7,8]$. During each PIV 1 epidemic, an estimated 18.000 to 35.000 U.S. children younger than 5 years are hospitalized [5,7-12]. Some of these children have bronchiolotis, tracheobronchitis, pneumonia and febrile and afebrile wheezing. The majority of infections occur in children aged 7 to 36 months, with a peak incidence in the second and third year of life. PIV 1 can cause LRI in young infants but is rare in those younger than 1 month. 
Citation: Tecu C, Mihai ME, Alexandrescu VI, Lupulescu E (2014) Concise Communications: "Death of a Patient Aged 2.5 Years after Infection Cause Parainfluenza Virus Type 1". J Med Microb Diagn 3: 166. doi:10.4172/2161-0703.1000166

Page 3 of 3

PIV 1 clearly cause acute inflammatory changes directly to airways and also are capable of inducing responses in the immune system that lead to acute pulmonary changes [13].

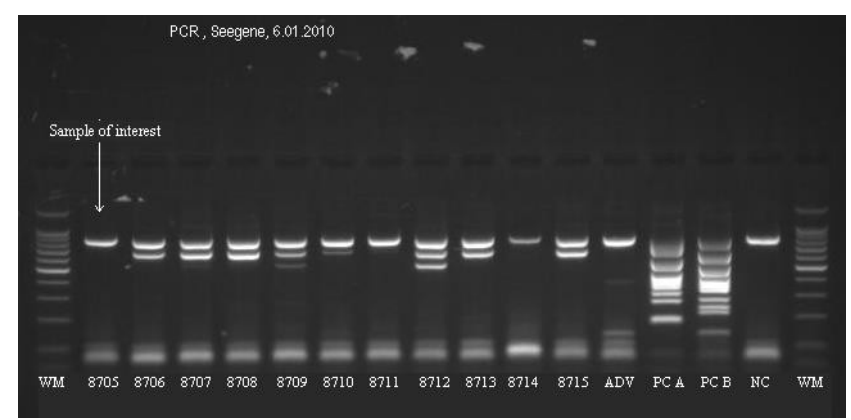

Figure 2: RV/PB 18 ASE Detection (See gene) (WM=Weight Molecular; 8705-8715=Tested Samples; ADV=Positive Control Adenovirus (134 bp); PC A=Positive Control Set A (Internal control-850 bp, Legionella pneumophila-753 bp, Chlamydophila pneumonia-593 bp, Mycoplasma pneumonia-469bp, Human Bocavirus-418bp, Human coronavirus 229E/NL 63, Human parainfluenza virus 1-324 bp, Human respiratory syncytial virus A-273 bp, Human enterovirus-194 bp, Influenza B virus-179 bp. PC $\mathrm{B}=$ Positive Control set B (Internal control-850 bp, Streptococcus pneumonia-673 bp, Haemophilus influenza- 534 bp, Influenza A virus-443 bp, Human Rhinovirus-394 bp, Human parainfluenzae virus 2-354 bp, Human coronavirus OC 43/HKU 1-289 bp, Human respiratory syncytial virus B-245 bp, Human parainfluenzae virus \#- 219 bp, Human adenovirus-134 bp. $\mathrm{NC}=$ Negative Control)

Mortality induced by PIV is unusual in developed countries and is seen almost entirely in young infants, the immunocompromised, and the elderly. However, the preschool population in developing countries has considerable risk of PIV-induced death. Whether by primary viral disease, LRI causes $25-30 \%$ of deaths in this age group and PIV causes at least $10 \%$ of the LRI [14]. In Romania there are no studies about the epidemiological data of circulation of PIV, and concerning the morbidity and mortality causing by these viruses. We signal in this study the possibility of the occurrence of death of a child aged 2.5 years, due to bronchopneumonia and cardio-respiratory failure caused by infection with parainfluenzae virus (PIV) type 1. Our sample was negative for A/H1N1 pandemic virus. Figure 1 shows the presence of major band appeared on agarose gel electrophoresis after carrying out RT-PCR as a positive control used in PIV type1. The analysis and interpretation of the results obtained from PCR for the 5 pneumonial bacteria (Figure 2) show that our sample is negative for these bacteria.

\section{Conclusion}

Finding of this study is that although the patient has no experienced chronic diseases associated with, she died from a bronhopneumonia caused by PIV type1.

\section{References}

1. Collins PL, Anderson K, Langer SJ, Wertz GW (1985) Correct sequence for the major nucleocapsid protein mRNA of respiratory syncytial virus. Virology 146: 69-77.

2. Ebihara T, Endo R, Kikuta H, Ishiguro N, Ishiko H, et al. (2004) Human metapneumovirus infection in Japanese children. J Clin Microbiol 42: 126-132.

3. Bellau-Pujol S, Vabret A, Legrand L, Dina J, Gouarin S, et al. (2005) Development of three multiplex RT-PCR assays for the detection of 12 respiratory RNA viruses. J Virol Methods 126: 53-63.

4. Carballal G, Videla CM, Espinosa MA, Savy V, Uez O, et al. (2001) Multicentered study of viral acute lower respiratory infections in children from four cities of Argentina, 1993-1994. J Med Virol 64: 167-174.

5. Marx A, Török TJ, Holman RC, Clarke MJ, Anderson LJ (1997) Pediatric hospitalizations for croup (laryngotracheobronchitis): biennial increases associated with human parainfluenza virus 1 epidemics. J Infect Dis 176: 1423-1427.

6. Murphy B, Phelan PD, Jack I, Uren E (1980) Seasonal pattern in childhood viral lower respiratory tract infections in Melbourne. Med J Aust 1: 22-24.

7. Denny FW, Murphy TF, Clyde WA Jr, Collier AM, Henderson FW (1983) Croup: an 11-year study in a pediatric practice. Pediatrics 71: 871-876.

8. Denny FW, Clyde WA Jr (1986) Acute lower respiratory tract infections in nonhospitalized children. J Pediatr 108: 635-646.

9. Belshe RB, Van Voris LP, Mufson MA (1983) Impact of viral respiratory diseases on infants and young children in a rural and urban area of southern West Virginia. J Epidemiol 117: 467-474.

10. Glezen WP, Frank AL, Taber LH, Kasel JA (1984) Parainfluenza virus type 3: seasonality and risk of infection and reinfection in young children. J Infect Dis 150: 851-857.

11. Henrickson KJ1, Kuhn SM, Savatski LL, Sedmak J (1994) Recovery of human parainfluenza virus types one and two. J Virol Methods 46: 189-205.

12. Skolnik NS (1989) Treatment of croup. A critical review. J Dis Child 143: 1045-1049.

13. Tuffaha A, Gern JE, Lemanske RF Jr (2000) The role of respiratory viruses in acute and chronic asthma. Clin Chest Med 21: 289-300.

14. Berman S (1991) Epidemiology of acute respiratory infections in children of developing countries. Rev Infect Dis 13 Suppl 6: S454-462. 